\section{Israel's scientist-President resigns}

EphraIM Katzir, the distinguished biochemist, has resigned as President of Israel to be replaced by a career politician-lzchak Navon. Katzir was Israel's fourth president, and the second scientist to hold the office. (Dr Chaim Weizmann was the first, and also the first president.)

Katzir took the opportunity of a recent visit by foreign scientists to Israel to indicate areas in which Israel should increase her scientific effort: principally, pollution control and industrial research.

Ex-president Katzir is concerned about the pollution of the Mediterranean and the Sea of Galilee, and the River Jordan. Israel shares her interest in the Mediterranean with many other countries, but Galilee and the Jordan are-relatively speaking-. local problems. Galilee, important for irrigation and fishing, is concentrating massive amounts of nitrate fertiliser, which runs off from the densely-packed agricultural holdings surrounding the lake. The Jordan is virtually dry due to the re-channelling of its waters, and is seriously polluted despite five or six years' effort to reduce the problem. The only pollution bright spot is industry, a fact Katzir attributed to Israel's lack of raw materials.

Katzir is returning to biochemical research-his lab remained empty while he was president-and hopes to help develop biotechnology and bioengineering in Israel. In his view the country's applied science needs improvement.

Among others, Michael Feldman, Professor of Biology at the Weizmann Institute, agrees with Katzir. "Applied science does lag behind basic science" he told Nature. The anomaly of science in Israel is the great success of agricultural research, contrasted with the limited success of industrial research. Agriculture has always been an essential activity for the Jews, even predating the establishment of Isreal as a state. Feldman points out that the early agronomists were able to enlist the help of scientists by clear presentation of well-defined problems -for example, those created by plant diseases. The symbiosis between agriculture and science has continued ever since.

Industry, however, has only developed during the past 20 years; it hardly existed during the early part of the century-and the embryonic Israeli industry was unable to define its problems.
THE great scientific debates continue. Recombinant DNA, ozone, nuclear energy, low-level insult, radioactive waste disposal, soft energy paths: they are constantly in the news.

Most of these issues lie at that ambiguous junction between science and society where science cannot give precise answers. Scientists with seemingly equal credentials often come to opposite scientific conclusions. Many of the questions are transscientific: they lie beyond the proficiency of science in principle. No wonder when debating these topics scientists sometimes represent as known what is only half-known, or apply lesser norms of scientific proof than they apply to conventional science.

Science, through its learned societies, has established the referee system to extirpate irresponsibility. It is hard to publish in the recognised journals of science, and rightly so. Even though a truly great idea is occasionally rejected, on the whole the system has maintained science as a responsible undertaking.

The system of peer review and refereeing is being undermined in many semi-scientific areas of inquiry. Take energy, a subject on which I spend most of my time. In the past few years no fewer than 40 journals in English devoted to energy and resources technology and policy have sprung up. I have no estimate of the number in other languages, but it is probably large. One need not read very far in this new literature to recognise that the refereeing is less strict than is the refereeing of the well-established disciplinary journals.

This is not necessarily the fault of the editor. It is rather that the fields are new, they involve many disciplines, and, as is so often the case with interdisciplinary investigations, the norms of acceptability are rather poorly defined. A physicist can hardly pass judgment on an economist, nor, for that matter, can the economist properly pass judgment on a physicist.

Can the scientific societies themselves, which have maintained the standards of responsibility within their own disciplines, help make these trans-scientific debates more responsible? Clearly, a good deal can be done. For example, the American Physical Society has now issued three major reports-on nuclear reactor safety, energy conservation, and nuclear fuel cycles and waste management. Each report as required intensive study by a dozen or so scientists, not all of whom are necessarily members of APS. Each report has been reviewed by a special Review

\section{Trans-science}

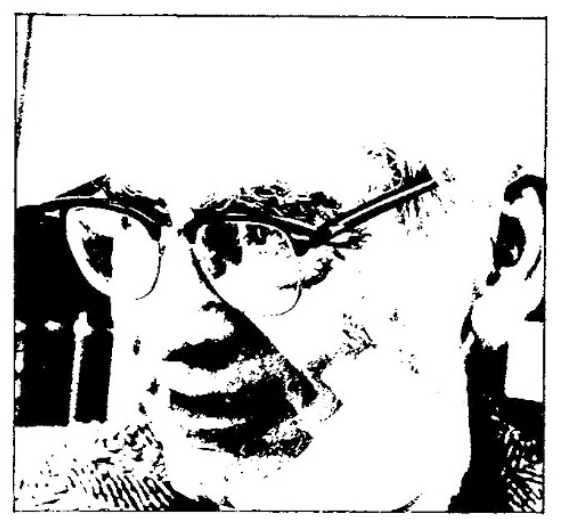

\section{ALVIN M. WEINBERG}

Committee of the American Physical Society, and in general, the scientific standards are high.

The best of the reports is the one on the nuclear fuel cycle and waste management. This is as careful and reasoned a scientific assessment of these touchy questions as exists. The group concluded that "For all LWR fuel cycle options, safe and reliable management of nuclear wastes and control of radioactive effluents can be accomplished with technologies that either exist or involve straightforward extension of existing capabilities".

These three reports, though generally, admirable, illustrate the difficulty when a society devoted to a single discipline tries to analyse an interdisciplinary issue. In both the reactor safety and the fuel cycle studies some assessment of the biological hazard of low-level radiation was essential. This lies outside the competence of physicists, yet neither the hazard of a reactor accident nor of the nuclear fuel cycle can be addressed without considering low-level radiation insult. The nuclear fuel cycle report to my mind exhibits a far more mature understanding of the matter than does the earlier report on reactor safety; yet I must concede that physicists talking about biology, however sensibly, are harder to believe than when they talk about radiation damage.

Despite this shortcoming, I believe the American Physical Society deserves great credit for undertaking serious studies of technologies that arise from physics. I view such involvement of established scientific societies in such trans-scientific questions as a hopeful way of injecting more responsibility into these debates. I hope other scientific societies will emulate the American Physical Society and help establish a more responsible technical literature in these controversial spheres of inquiry. 